\title{
Correction to: Evaluating research performance of research institutes within Malaysian universities: an alternative assessment framework
}

\section{Goh Choo Ta ${ }^{1}$. Sharina Abdul Halim ${ }^{1}$. Norzaini Azman ${ }^{2} \cdot$ Ibrahim Komoo $^{1}$. Mazlin Mokhtar ${ }^{1}$}

Published online: 26 November 2021

(c) The European Higher Education Society 2021

\section{Correction to: Tertiary Education and Management https://doi.org/10.1007/s11233-021-09080-6}

The last reference (Soh, K. 2015) contains incomplete details.

"Soh, K. (2015). What the Overall doesn't tell about world university rankings: examples from."

The corrected reference is shown below:

"Soh, K. (2015). What the Overall doesn't tell about world university rankings: examples from ARWU, QSWUR, and THEWUR in 2013. Journal of Higher Education Policy and Management, 37 (3), 295-307"

The original article has been corrected.

Publisher's note Springer Nature remains neutral with regard to jurisdictional claims in published maps and institutional affiliations.

The original article can be found online at https://doi.org/10.1007/s11233-021-09080-6.

Norzaini Azman

norzai12@ukm.edu.my

Goh Choo Ta

gohchoota@ukm.edu.my

Sharina Abdul Halim

sharinahalim@ukm.edu.my

Ibrahim Komoo

ikomoo@ukm.edu.my

Mazlin Mokhtar

mazlin@ukm.edu.my

1 Institute for Environment and Development (LESTARI), Universiti Kebangsaan Malaysia (UKM), Bangi, Malaysia

2 Centre for Educational Leadership and Policy, Faculty of Education, Universiti Kebangsaan Malaysia (UKM), Bangi, Malaysia 